\title{
A Microsoft Learning Content Development System (LCDS) Based Learning Package for Electrical and Electronics Technology-Issues on Acceptability and Usability in Nigeria
}

\author{
Ayotola AREMU ${ }^{1, *}$, Bamidele Michael EFUWAPE \\ ${ }^{1}$ Department of Teacher Education, University of Ibadan, Ibadan, Nigeria \\ ${ }^{2}$ Vocational and Technical Education Department, Tai Solarin University of Education, Ijebu-Ode, Nigeria \\ *Corresponding author: ayotk2001@yahoo.com
}

Received January 21, 2013; Revised February 13, 2013; Accepted March 19, 2013

\begin{abstract}
This study reported the use of a Free Open Source Software (FOSS), the Microsoft Learning Content Development System (Ms LCDS) to design and develop a learning package in electrical and electronic technology for teaching thermionic emission and investigated the acceptability and usability of the learning package. This study adopted a descriptive survey design. 80 students of electrical and electronics engineering and technology were randomly selected from two higher institutions in the country. A structured questionnaire with a reliability coefficient of 0.89 was used for data collection. Six research questions were raised and data collected was analysed using mean, standard deviation and Multiple Regression at 0.05 level of significance. The research findings revealed high acceptability and usability levels of the learning package (Mean=5.14 and Mean=3.35 respectively). A significant joint effect of self-efficacy, attitude and subjective satisfaction was revealed on acceptability $\left(\mathrm{F}_{(3,76)}\right.$ $=9.458 ; \mathrm{p}<0.05$ ) while a significant joint effect of perceived enjoyment, self-efficacy, attitude and subjective satisfaction was revealed on usability $\left(\mathrm{F}_{(4,75)}=9.418 ; \mathrm{p}<0.05\right)$. Based on the findings, it is recommended amongst other things that computer assisted materials or packages be developed for topics that may need some extra support to teach.
\end{abstract}

Keywords: traditional teaching approach, electrical and electronics technology, technology-based learning package, FOSS, LCDS, acceptability, usability

\section{Introduction}

\subsection{Preamble}

As a result of the rapid development of the information and communication technology (ICT), the use of computers in education has become inevitable. The use of technology in education provides the students with a more suitable environment to learn, serves to create interest and a learning centered-atmosphere, and helps increase the students' motivation. The use of technology in this way plays an important role in the teaching and learning process [17]. Advances in computer technology have caught the attention of many educators and researchers. Computer-based multimedia applications, because of their flexible and varied presentation capabilities, are considered an effective alternative to traditional training methods.

Many problems have been identified with traditional teaching approaches, which was based on behaviorism. In traditional teaching, the teacher is the authority and the students are passive learners [7]. Traditional approach to education is characterized by a talking teacher standing in front of the students; the pupils are with exercise books and other writing materials, the use of chalk and blackboard for writing, among others. Electrical and electronics technology, as a science and technology course and also a branch of Physics, had witnessed series of setbacks and difficulties in achieving its aim. This is because many of its concepts are abstract in nature. This makes the course difficult to comprehend for students and difficult for teachers to teach in Nigerian schools. There are several reasons for the difficulties encountered in the teaching and learning of these scientific concepts in Nigerian schools. Such reasons include; lack of resource based materials, incompetent science teachers, inappropriate teaching tools, wrong methodology, among others. Many times, the concepts cannot be easily linked with the daily activities. In a study by [1], it was stated that the reason for not reaching the aims in the lessons involving abstract concepts like law of Snell in Physics was because of the application of traditional approaches. The studies on traditional method of instructions such as $[2,22]$ among others has revealed the inability of the method to bridge the gap between abstract and reality of a course as experienced in teaching of some topics in electrical and electronics technology in the tertiary institutions. 
Reference [13] however identified teaching situations peculiar to the teaching/learning process in Nigeria which include the problem of large classes; the problem of limited facilities; incompetent science teachers, inadequate and inefficient teaching tools, wrong methods of teaching and the problem of multi-grade classes. This affects particularly the teaching of Science and Technology.

Electrical and electronics engineering is a field of study, which is so germane to any country's economy and development as well as the well being of the citizens. The supply of the much needed electricity in carrying out different daily activities which enhances economic growth and development of the nations of the world and all electronic gadgets which enhances the livelihood of the citizens is one of the major benefits of this field of study. In order to ensure effective teaching of the concepts of electrical and electronic technology such as structures of matter, Archimedes principle, Law of floatation among many others and to provide a guide for science students against the negative effects of the rote-memory based education system the development of computer-based learning package is required.

\subsection{Computer Based Teaching and Learning}

Today in many educational and training settings, interactive computer programs are used to teach young students and adults computer literacy skills [2]. There is the need to promote interactivity in teaching and learning because learners learn better when they are actively involved in the teaching and learning process. The level of interactivity introduced into teaching and learning practices by engaging the learners with different instructional activities will help to determine the learners understanding of the concept. In parallel with the technological advances: technological devices, particularly computers began to be used in educational environments to develop audio-visual materials such as animation and simulation, which resulted in the development of the computer-based instruction techniques [17]. One of the features that make this attractive to learners is the fact that concepts can be visibly displayed to learners which make learning more meaningful when the latest technologies are used unlike the traditional method where it is totally or purely abstraction.

The computer-based teaching has had an impact on the development of the educational technology to a great extent in the $21^{\text {st }}$ century and this has resulted in the production of software for the computer-based instruction. The primary purpose of education software is to solve the learning problems in the science courses encountered by the school students, to increase their motivation and achievements and to serve as a guide against the negative effect of the rote-memory based education system [17].

There are educational products designed to be used in the computer-based and computer-supported teaching practices. Educational software developed to prepare computer based instructions have various features which would take care of teaching and learning difficulties encountered in science and engineering courses, an example of these software is open source software (OSS). According to [18], Free Open Source Software (FOSS) is characterized by four kinds of freedom, for the users of the software: The freedom to run the program, for any purpose, the freedom to study how the program works, and adapt it to your needs, the freedom to redistribute copies so you can help your neighbor and the freedom to improve the program, and release your improvements to the public, so that the whole community benefits. Several free software and Open Source Software are available, but certain features need to be considered in choosing a particular type of FOSS. The subject characteristics, learner's characteristics and learning outcomes are part of things to consider in recommending a particular FOSS in an instructional situation. Aside from FOSS desktop applications for general use, there are a lot of Free/Open Source educational software that can be used for teaching specific subjects or courses in schools, colleges and universities. These range from drawing programs for young students (e.g., Tux Paint) to programs for learning geometry (e.g., Kig), chemistry (e.g., Ghemical). For higher education, there is QCAD, a program for Computer-Aided Drafting that may be used in technical drawing classes. Scilab is a full-featured scientific software package that may be used in numerical analysis or engineering courses at the university level. Learning Content Development System (LCDS) is another free open source software that is used for creation and publishing of electronic courses.

\subsection{Microsoft Learning Content Design System}

The MsLCDS is free software from Microsoft and is a free tool that enables the Microsoft Learning community to create high-quality, interactive, online courses. The LCDS allows anyone in the Microsoft Learning community to publish e- learning courses by completing the easy-to-use LCDS forms that seamlessly generate highly customized content, interactive activities, quizzes, games, assessments, animations, demos, and other multimedia. You can include software simulations, interactive Flash content (such as Drag and Drop, tile puzzle game, etc.) and the regular true-false / multiple choice style questions in the e-learning content. The Learning Content Development System (LCDS) is an e learning system designed to aid individuals in creating interactive online courses [4]. Electrical and electronic concepts which are mostly abstract in nature needs inclusion of certain features of technology to bring the lessons closely to the learners and features that can enhance and achieve this are present in LCDS and other types of FOSS. LCDS is so fascinating for electrical and electronics courses with the features that reduces abstraction in teaching of such concepts, and so is chosen for the purpose of this study. This software can be modified to suite other purpose when desired. Therefore it is preferred for this study. The LCDS helps to create content with text and pictures, interactive activities, quizzes, games, assessments, animations, demos, and other multimedia. It also provides the decision to embed pictures, movies, audio files, flash and silverlight content into the course. These features of LCDS and its support for teaching and learning gives a clear indication that it would be appropriate to design and develop a learning package suitable for teaching and learning of electrical and electronic technology concepts. 
Accepting any software based learning package is one of the most important decisions if that software would deliver value. Yet, there exists little guidance about what this decision should be based on and how to make it effectively [9]. Computer systems cannot improve organisational performance if they are not used. To better predict, explain, and increase user acceptance, we need to better understand why people accept or reject computers or technology generally. The acceptance of computer technology could be gotten from the measure of user's intentions, and the ability to explain their intentions in terms of their attitudes, subjective norms, perceived usefulness, perceived ease of use, and related variables [20]. For the purpose of ascertaining the acceptability and usability of this software, it is evident that tests will be required to sample the opinion and degree of acceptance of this technology by the prospective users.

\subsection{Technology Acceptability and Usage}

The use of computers in education due to its positive effect to increase the attention and curiosity of students, and the helps it provides in the conceptual learning, is spreading widely. In addition, most of the knowledge related to natural phenomenon is now available in the computer environment $[1,3,15]$. That is why, when teachers use computers and other technologies as a teaching tool, this would give them the ability to show the physical phenomenon in a way that students can visualize in a three dimensional form. Visually observing the subject under study would help the students to consolidate the knowledge gained and find ways to link this to their surroundings [15]. Reference [1] disclosed that the most familiar objective of the science education is to teach learners the science concepts in a meaningful way and enable them to learn how they can make use of these concepts in their daily lives; acceptance and usage of technology based instruction can enhance this.

Acceptance and usage of modern communication technologies such as computer, CD's, slides, video, mobile phones, IPAD, IPODs, sound and animations in science and technology courses for teaching and learning makes it possible to have an interactive lesson and thereby increase the range of students' learning style. A wide range of instructional strategies must be used to engage different learning styles and encourage learning through hands-on activities [11].

Despite significant technological advances and increasing organisational investment in technologies, the problem of underutilized systems plagues Nigeria education system. According to a study (e.g [3]), regardless of the way one view technology, usability plays an important role in all quality perspectives. Computer systems cannot improve academic performance if they are not used. To better predict, explain, and increase user acceptance, we need to better understand why people accept or reject computers or technology generally. Reference [9] disclosed that majority of approaches dealing with technology acceptance refer to the acceptance of ICT-technologies in a job-related context. Theories of technology acceptance consider mainly two key components of technology acceptance: the perceived usefulness (PU) and the perceived ease of use (PEoU), these are key determinants of individual's intention to use a technical system. The acceptance of computer technology could be gotten from the measure of user's intentions, and the ability to explain their intentions in terms of their attitudes, subjective norms, perceived usefulness, perceived ease of use, and related variables [20].

Reference [10] revealed in his study that perceived usefulness strongly influences peoples' intentions to accept and use technology. Reference [10] further observed that perceived ease of use had a small but significant effect on intentions as well, although this effect subsided over time. Attitudes only partially mediated the effects of these beliefs on intentions and subjective norms had no effect on intentions [10].

Perceived usefulness and ease of use are each highly correlated with self-reported use and future use [20]. Reference [15] disclosed that ease of use appears to be a causal antecedent of usefulness, with little direct effect on use. Often users of new technology experience cognitive dissonance in understanding the benefits of using the new technology, while still being resistant to change and uncertainty. The user's current level of satisfaction with computers and technology influence their future usage of new technology and software. Reference [5] suggests attitude toward computers is the most important aspect of a successful human-computer relationship. She also discusses self-efficacy as an important determinant of successful computer adoption. Self efficacy regarding computer usage is an individual's belief regarding his or her ability to successfully master a computer [3]. Reference [5] linked "favorable attitudes" toward technology with the following factors: training, early adoptor, attitude toward new technology, and likeness for using computers. This research will ascertain the level of acceptance and usability of the designed and developed learning package from the measure of learners' intentions in terms of their attitudes, perceived usefulness, perceived ease of use, satisfaction and operability.

It then seems that understanding user acceptance, adoption, and usage of new systems is a high priority item for researchers and practitioners alike. Moreover, [20] reported a significant body of research in information systems (IS) (e.g., Davis et al. 1989, Venkatesh 1999) and human-computer interaction (HCI) (e.g., Gould and Lewis 1985) has accumulated support for the importance of perceived ease of use on initial user acceptance and sustained usage of systems. With the level of individual interest and intention to use technology, willingness and openness to using technology; values attached to technology; user's expectations and needs; attitude towards and specific acceptance motives of technology which differ from one person to the other; it is imperative in this study to ascertain the level of learner's acceptance of technology package for learning. The level of technology acceptance determines its effectiveness in use and productivity.

\section{Purpose of the Study}

This study, aims at investigating the levels of learner's acceptability and usability of a Free Open Source Software (FOSS) Based Learning Package for learning among the Electrical and Electronics Engineering Students. 
The following research questions were investigated based on the aim stated above:

1. What is the level of acceptability of the FOSS-based learning package?

2. Is learner's acceptability of FOSS package based on self efficacy, attitude and subjective satisfaction?

3. What is the relative effect of self-efficacy, attitude and subjective satisfaction on learner's acceptability of a FOSS-based learning package?

4. What is the level of usability of the FOSS-based learning package?

5. Is learner's level of usability determined by perceived enjoyment, self efficacy, attitude and subjective satisfaction?

What is the relative effect of perceived enjoyment, selfefficacy, attitude and subjective satisfaction on learner's usability of a FOSS-based learning package?

\section{Methodology}

\subsection{Design and Development of Learning Package}

In the study, a learning package on electrical and electronics technology was designed and developed using the MsLCDS. The order of Govindasamy (2002) was adopted for the package design and development because it conforms to the phases in product development. The Govindasamy (2002) model consists of five stages, namely: Analysis, Design, Development, Formative Evaluation, and Production. These stages dovetail into nine steps namely: Learner analysis, Task analysis, Defining instructional objectives, Selecting instructional strategies, Preparation of first draft material, Review by content expert, One-to-one trial, Small Group Trial, and Production of the first version of the e- Learning module. The stages were carefully observed in producing the instructional package. The package was developed to teach thermionic emission in electrical and electronics. Five topics including thermionic valves, thermionic diode, the triode valve, the tetrode valve and the pentode valve were treated with various medias and activities incorporated in the package. The package was validated using experts' evaluation scale and user rating scale.

\subsection{Research Design}

A descriptive survey design of the ex-post facto research was adopted for the study. 40 students each from two tertiary institutions were involved in the study. The respondents were 200 Level and First Year Students of National Diploma (ND1) in the department of Electrical and Electronics engineering and Technology in a University and a Polytechnic in Ogun State. The total number of 80 students involving 18 females and 62 males were respondents for the study. The developed FOSSbased learning package and 43 questionnaire items were used as the data collection tool. The designed and developed package was presented to each student for interaction and self-controlled learning; and later the structured questionnaire was administered to the respondents for data collection.

\subsection{Acceptability and Usability Questionnaire}

A structured questionnaire was used to determine the acceptability and usability of the technology-based learning package used in the teaching and learning process. The questionnaire items were divided into acceptability and usability testing section. Perceived ease of use (expectation that a technology requires minimum effort) and perceived usefulness (perception that the use of a technology can enhance performance of a task at hand) were used for acceptability testing while actual use (the level of technology use) was used for usability testing. Perceived enjoyment, self efficacy, behavioural intentions and subjective satisfaction were the independent variables for the study. Perceived enjoyment refers to the pleasure, excitement and benefits experienced while using a technology; Self efficacy refers to an individual's beliefs about his ability to use or interact with a technology (to execute a particular performance); Behavioural intention refers to the positive or negative value the individual associates to a technology which in turn determine the future use of such technology (intention to continuously use the technology or not); Subjective satisfaction refer to the level of preference a user have for the used technology (it has to do with interface satisfaction, ease of interactivity etc.). User technology acceptance and use are dependent on these variables among others, so they are used in this study to determine the learner's level of acceptability and usability of the MsLCDS learning package. The instrument was validated using cronbach alpha and a reliability coefficient of 0.89 was obtained.

\section{Results}

\subsection{Research Question 1}

The first research question for the study was "What is the level of acceptability of the FOSS-based learning package?" Findings obtained are presented in Table 1

Table 1 shows the level of acceptability of the Fossbased learning package where some of the respondents indicated that the following are quite likely: Learning through a FOSS package is easy for me $(x=5.49)$, I find the package flexible to interact with $(x=5.41)$, It is easy for me to become skillful at using the package for learning $(x=5.40)$, I find the FOSS Package easy to use ( $x=5.21)$, I find it easy to get the FOSS package to do what I want it to do $(x=4.65)$, Using FOSS package for my learning would enable me to accomplish tasks more quickly $(x=5.45)$, Using the package would improve my academic performance $(x=5.34)$, Using the package would enhance my effectiveness in school $(x=5.33)$, Using the package would make it easier for me to do my work $(x=5.40)$, Using FOSS package would increase my academic productivity $(\mathrm{x}=5.46)$, I find FOSS Package useful in my studies $(\mathrm{x}=5.39)$ and FOSS package would make it easier to study course content $(\mathrm{x}=5.31)$.

The table also shows that some of the respondents indicated that it is extremely likely that their interaction with the package will be clear and understandable $(x=5.50)$. Again the table shows that some of the respondents indicated that it is slightly unlikely that the package makes the lesson more difficult $(x=2.56)$. 
The weighted average mean, as shown in the table is higher than 3.50 which is accepted in this study as level of high acceptability, it can be concluded that the level of acceptability of the FOSS-based learning package is high.

Table 1. Level of Acceptability of the FOSS-based Learning Package

\begin{tabular}{|c|c|c|c|c|c|c|c|c|c|}
\hline $\mathrm{S} / \mathrm{N}$ & ITEMS & EL & QL & SL & SU & QU & EU & Mean & Std. Dev. \\
\hline & PERCEIVED EASE OF USE & & & & & & & & \\
\hline 1 & $\begin{array}{l}\text { Learning through a FOSS package is easy for } \\
\text { me. }\end{array}$ & $\begin{array}{c}45 \\
(56.2)\end{array}$ & $\begin{array}{c}29 \\
(36.2)\end{array}$ & $\begin{array}{c}6 \\
(7.5) \\
\end{array}$ & $(0.0)$ & $\begin{array}{c}- \\
(0.0)\end{array}$ & $(0.0)$ & 5.49 & 0.64 \\
\hline 2 & $\begin{array}{l}\text { My interaction with the package is clear and } \\
\text { understandable. }\end{array}$ & $\begin{array}{c}50 \\
(62.5) \\
\end{array}$ & $\begin{array}{c}24 \\
(30.0) \\
\end{array}$ & $\begin{array}{c}4 \\
(5.0) \\
\end{array}$ & $\begin{array}{c}1 \\
(1.2) \\
\end{array}$ & $(0.0)$ & $\begin{array}{c}1 \\
(1.2)\end{array}$ & 5.50 & 0.83 \\
\hline 3 & I find the package flexible to interact with. & $\begin{array}{c}48 \\
(60.0)\end{array}$ & $\begin{array}{c}21 \\
(26.2)\end{array}$ & $\begin{array}{c}9 \\
(11.2)\end{array}$ & $\begin{array}{c}1 \\
(1.2)\end{array}$ & $\begin{array}{c}1 \\
(1.2)\end{array}$ & $(0.0)$ & 5.41 & 0.70 \\
\hline 4 & $\begin{array}{l}\text { It is easy for me to become skillful at using } \\
\text { the package for learning. }\end{array}$ & $\begin{array}{c}47 \\
(58.8)\end{array}$ & $\begin{array}{c}25 \\
(31.2)\end{array}$ & $\begin{array}{c}5 \\
(6.2)\end{array}$ & $\begin{array}{c}1 \\
(1.2)\end{array}$ & $\begin{array}{c}- \\
(0.0)\end{array}$ & $\begin{array}{c}2 \\
(2.5)\end{array}$ & 5.40 & 0.98 \\
\hline 5 & I find the FOSS Package easy to use. & $\begin{array}{c}34 \\
(42.5)\end{array}$ & $\begin{array}{c}32 \\
(40.0)\end{array}$ & $\begin{array}{c}13 \\
(16.2)\end{array}$ & $(0.0)$ & $(0.0)$ & $\begin{array}{c}1 \\
(1.2)\end{array}$ & 5.21 & 0.87 \\
\hline 6 & The package makes the lesson more difficult. & $\begin{array}{c}6 \\
(7.5) \\
\end{array}$ & $\begin{array}{c}7 \\
(8.8) \\
\end{array}$ & $\begin{array}{c}9 \\
(11.2) \\
\end{array}$ & $\begin{array}{c}12 \\
(15.0)\end{array}$ & $\begin{array}{c}16 \\
(20.0) \\
\end{array}$ & $\begin{array}{c}30 \\
(37.5) \\
\end{array}$ & 2.56 & 1.64 \\
\hline 7 & $\begin{array}{l}\text { I find it easy to get the FOSS package to do } \\
\text { what I want it to do. }\end{array}$ & $\begin{array}{c}27 \\
(33.8) \\
\end{array}$ & $\begin{array}{c}25 \\
(31.2) \\
\end{array}$ & $\begin{array}{c}17 \\
(21.2) \\
\end{array}$ & $\begin{array}{c}1 \\
(1.2) \\
\end{array}$ & $\begin{array}{c}4 \\
(5.0) \\
\end{array}$ & $\begin{array}{c}6 \\
(7.5) \\
\end{array}$ & 4.65 & 1.47 \\
\hline & PERCEIVED USEFULNESS & & & & & & & & \\
\hline 8 & $\begin{array}{l}\text { Using FOSS package for my learning would } \\
\text { enable me to accomplish tasks more quickly. }\end{array}$ & $\begin{array}{c}44 \\
(55.0)\end{array}$ & $\begin{array}{c}29 \\
(36.2)\end{array}$ & $\begin{array}{c}6 \\
(7.5) \\
\end{array}$ & $\begin{array}{c}1 \\
(1.2)\end{array}$ & $(0.0)$ & $(0.0)$ & 5.45 & 0.69 \\
\hline 9 & $\begin{array}{l}\text { Using the package would improve my } \\
\text { academic performance. }\end{array}$ & $\begin{array}{c}41 \\
(51.2)\end{array}$ & $\begin{array}{c}28 \\
(35.0)\end{array}$ & $\begin{array}{c}10 \\
(12.5) \\
\end{array}$ & $(0.0)$ & $(0.0)$ & $\begin{array}{c}1 \\
(1.2)\end{array}$ & 5.34 & 0.86 \\
\hline 10 & $\begin{array}{l}\text { Using the package would enhance my } \\
\text { effectiveness in school. }\end{array}$ & $\begin{array}{c}44 \\
(55.0) \\
\end{array}$ & $\begin{array}{c}24 \\
(30.0) \\
\end{array}$ & $\begin{array}{c}9 \\
(11.2) \\
\end{array}$ & $\begin{array}{c}1 \\
(1.2) \\
\end{array}$ & $\begin{array}{c}1 \\
(1.2)\end{array}$ & $\begin{array}{c}1 \\
(1.2)\end{array}$ & 5.33 & 0.97 \\
\hline 11 & $\begin{array}{l}\text { Using the package would make it easier for } \\
\text { me to do my work. }\end{array}$ & $\begin{array}{c}42 \\
(52.5)\end{array}$ & $\begin{array}{c}29 \\
(36.2)\end{array}$ & $\begin{array}{c}8 \\
(10.0)\end{array}$ & $\begin{array}{c}1 \\
(1.2)\end{array}$ & 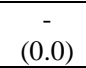 & $(0.0)$ & 5.40 & 0.72 \\
\hline 12 & $\begin{array}{l}\text { Using FOSS package would increase my } \\
\text { academic productivity. }\end{array}$ & $\begin{array}{c}46 \\
(57.5)\end{array}$ & $\begin{array}{c}26 \\
(32.5)\end{array}$ & $\begin{array}{c}7 \\
(8.8)\end{array}$ & $\begin{array}{c}1 \\
(1.2)\end{array}$ & $(0.0)$ & $(0.0)$ & 5.46 & 0.71 \\
\hline 13 & I find FOSS Package useful in my studies. & $\begin{array}{c}43 \\
(53.8) \\
\end{array}$ & $\begin{array}{c}25 \\
(31.2) \\
\end{array}$ & $\begin{array}{c}12 \\
(15.0) \\
\end{array}$ & $(0.0)$ & - & $(0.0)$ & 5.39 & 0.74 \\
\hline 14 & $\begin{array}{l}\text { FOSS package would make it easier to study } \\
\text { course content. }\end{array}$ & $\begin{array}{c}43 \\
(53.8)\end{array}$ & $\begin{array}{c}25 \\
(31.2)\end{array}$ & $\begin{array}{c}10 \\
(12.5)\end{array}$ & $(0.0)$ & $(0.0)$ & $\begin{array}{c}2 \\
(2.5) \\
\end{array}$ & 5.31 & 0.99 \\
\hline & Weighted Average Mean & \multicolumn{8}{|c|}{5.14} \\
\hline
\end{tabular}

\subsection{Research Question 2}

The second research question for the study was "Is learners' acceptability of FOSS package based on self efficacy, attitude and subjective satisfaction?" Findings obtained from this sub problem are presented in Table 2.

Table 2 shows the joint influence of subjective satisfaction, self-efficacy and behavioral intentions on learner's acceptability of the FOSS-based package. The table shows that there is a positive joint relationship between the independent variables $(\mathrm{R}=.521)$. The table shows further that the coefficient of determinant (Adjusted $\mathrm{R}^{2}=0.243$ ) indicates that the independent variables accounted for $24.3 \%$ of the total variance in the learner's acceptability of the FOSS package (Adjusted $R^{2}$ x $100=$ 24.3). This joint effect is shown to be significant on the learner's acceptability of the FOSS-based package $\left(\mathrm{F}_{(3,76)}\right.$ $=9.458 ; \mathrm{P}<0.05)$.

Since the joint effect of the independent variables on the dependent variable is significant, it can be concluded that learner's acceptability of the FOSS-based package is based on self efficacy, attitude and subjective satisfaction.

\subsection{Search Question 3}

The third question of the study was "What is the relative effect of self-efficacy, attitude and subjective satisfaction on learner's acceptability of a FOSS-based learning package?". Findings obtained from this sub problem are presented in Table 3 .
Table 2. Summary of Multiple Regression showing Joint Influence of Self-Efficacy, Attitude and Subjective Satisfaction on Learners Acceptability of FOSS-Package

Acceptability of FOSS-Package
\begin{tabular}{|c|c|c|c|c|c|c|}
\hline \multicolumn{7}{|c|}{$\begin{array}{c}\text { R }=.521 \\
\text { R Square }=.272 \\
\text { Adjusted } \mathrm{R}^{2}=.243 \\
\text { Std. Error= 5.40326 }\end{array}$} \\
\hline \multicolumn{7}{|c|}{ Analysis of Variance } \\
\hline Model & $\begin{array}{c}\text { Sum of } \\
\text { Squares }\end{array}$ & Df & $\begin{array}{c}\text { Mean } \\
\text { Square }\end{array}$ & F & Sig. & Remark \\
\hline Regression & 828.366 & 3 & 276.122 & 9.458 & .000 & Significant \\
\hline Residual & 2218.834 & 76 & 29.195 & & & \\
\hline Total & 3047.200 & 79 & & & & \\
\hline Predictors: Subjective Sations
\end{tabular}

Predictors: Subjective Satisfaction, Self-Efficacy, Behavioral Intentions (attitude)

Dependent Variable: Acceptability

Table 3. Relative Contribution of Self Efficacy, Attitude and Subjective Satisfaction to Learner's Acceptability of Foss Package

\begin{tabular}{|c|c|c|c|c|c|}
\hline \multirow{2}{*}{ Model } & \multicolumn{2}{|c|}{$\begin{array}{c}\text { Unstandardized } \\
\text { Coefficients }\end{array}$} & $\begin{array}{c}\text { Standardized } \\
\text { Coefficients }\end{array}$ & \multirow{2}{*}{$\mathrm{T}$} & \multirow{2}{*}{ Sig. } \\
\cline { 2 - 5 } & $\mathrm{B}$ & $\begin{array}{c}\text { Std. } \\
\text { Error }\end{array}$ & Beta & & .000 \\
\hline Constant & 36.884 & 6.634 & & 5.560 & .000 \\
\hline Self Efficacy & 1.267 & .558 & .230 & 2.272 & .026 \\
\hline $\begin{array}{c}\text { Behaviour } \\
\text { Intentions }\end{array}$ & .676 & .366 & .197 & 1.849 & .068 \\
\hline $\begin{array}{c}\text { Subjective } \\
\text { Satisfaction }\end{array}$ & .491 & .169 & .304 & 2.899 & .005 \\
\hline
\end{tabular}

Table 3 shows the relative contribution of Self Efficacy, Attitude and Subjective Satisfaction on Learner's Acceptability of Foss Package. The table shows that 
subjective satisfaction has highest contribution $(\beta=.304)$ which is followed by self-efficacy $(\beta=.230)$. Behavioral intentions had the least contribution $(\beta=.197)$.

\subsection{Research Question 4}

The fourth research question for the study was "What is the level of usability of the FOSS-based learning package?" Findings obtained from this sub problem are presented in Table 4.
Table 4 shows the level of Usability of the Foss-based learning package. The table shows that all the respondents indicated their agreement with the following: The package was simple and easy to use (X=3.48), I could effectively complete the tasks using the FOSS package $(X=3.25)$, I was able to complete the tasks quickly using this package $(x=3.26)$, I was able to efficiently complete the tasks using this package $(x=3.35)$, I was able to interact with the package effectively and self control the direction and pace of learning $(\mathrm{x}=3.41)$.

Table 4. Level of Usability of the FOSS-based Learning Package

\begin{tabular}{|c|c|c|c|c|c|c|c|}
\hline $\mathrm{S} / \mathrm{N}$ & ITEMS & SA & A & D & SD & Mean & $\begin{array}{l}\text { S/Deviati } \\
\text { on }\end{array}$ \\
\hline & ACTUAL USE & & & & & & \\
\hline 15 & The package was simple and easy to use. & $\begin{array}{c}40 \\
-50\end{array}$ & $39(48.8)$ & $-(0.0)$ & $1(1.2)$ & 3.48 & 0.57 \\
\hline 16 & $\begin{array}{l}\text { I could effectively complete the tasks using the FOSS } \\
\text { package. }\end{array}$ & $\begin{array}{c}28 \\
-35\end{array}$ & $\begin{array}{c}46 \\
-57.5\end{array}$ & $\begin{array}{c}4 \\
-5 \\
\end{array}$ & $\begin{array}{c}2 \\
-2.5 \\
\end{array}$ & 3.25 & 0.67 \\
\hline 17 & $\begin{array}{l}\text { I was able to complete the tasks quickly using this } \\
\text { package. }\end{array}$ & $\begin{array}{c}27 \\
-33.8 \\
\end{array}$ & $\begin{array}{c}47 \\
-58.8 \\
\end{array}$ & $\begin{array}{c}6 \\
-7.5 \\
\end{array}$ & - & 3.26 & 0.59 \\
\hline 18 & $\begin{array}{l}\text { I was able to efficiently complete the tasks using this } \\
\text { package. }\end{array}$ & $\begin{array}{c}31 \\
-38.8 \\
\end{array}$ & $\begin{array}{c}47 \\
-58.8 \\
\end{array}$ & $\begin{array}{c}1 \\
-1.2 \\
\end{array}$ & $\begin{array}{c}1 \\
-1.2 \\
\end{array}$ & 3.35 & 0.58 \\
\hline 19 & $\begin{array}{l}\text { I was able to interact with the package effectively and } \\
\text { self control the direction and pace of learning. }\end{array}$ & $\begin{array}{l}36 \\
-45 \\
\end{array}$ & $\begin{array}{c}41 \\
-51.2 \\
\end{array}$ & $\begin{array}{c}3 \\
-3.8 \\
\end{array}$ & $-\overline{0}$ & 3.41 & 0.57 \\
\hline & Weighted Average Mean & \multicolumn{6}{|c|}{3.35} \\
\hline
\end{tabular}

However, since weighted average mean, as shown in the table is higher than 2.50 which is accepted in this study as level of high usability, it can be concluded that the level of usability of the learning package is high.

\subsection{Research Question 5}

The fifth research question for the study was "Is learner's level of usability determined by perceived enjoyment, self efficacy, attitude and subjective satisfaction?". Findings obtained from this sub problem are presented in Table 5 .

Table 5. Summary of Multiple Regression showing Joint Influence of Perceived Enjoyment, Self-Efficacy, Attitude and Subjective Satisfaction on Learner's Usability of FOSS-Package

Satisfaction on Learner's Usability of FOSS-Package
\begin{tabular}{|c|c|c|c|c|c|c|}
\hline \multicolumn{7}{|c|}{$\begin{array}{c}\text { R } .578 \\
\text { Adjusted R2 }=.299 \\
\text { Std. Error }=1.50441\end{array}$} \\
\hline Model & $\begin{array}{c}\text { Sum of } \\
\text { Squares }\end{array}$ & Df & $\begin{array}{c}\text { Mean } \\
\text { Square }\end{array}$ & F & Sig. & Remark \\
\hline Regression & 85.257 & 4 & 21.314 & 9.418 & 0 & Significant \\
\hline Residual & 169.743 & 75 & 2.263 & & & \\
\hline Total & 255 & 79 & & & & \\
\hline
\end{tabular}

Predictors: Perceived Enjoyment, Subjective Satisfaction, Self-Efficacy, Behavior Intentions

Dependent Variables: Usability

Table 5 shows the joint influence of perceived enjoyment, subjective satisfaction, self-efficacy and behavioral intentions on learner's usability of the FOSSbased package. The table shows that there is a positive joint relationship between the independent variables ( $R$ $=.578)$. The table shows further that the coefficient of determinant (Adjusted $\mathrm{R}^{2}=0.299$ ) indicates that the independent variables accounted for $29.9 \%$ of the total variance in the learner's usability of the FOSS package (Adjusted $\mathrm{R}^{2} \times 100=29.9$ ). This joint effect is shown to be significant on the learner's usability of the FOSS-based package $\left(\mathrm{F}_{(4,75)}=9.418 ; \mathrm{P}<0.05\right)$. Since the joint effect of the independent variables on the dependent variable is significant, it can be concluded that learner's usability of the FOSS-based package is based on perceived enjoyment, self efficacy, attitude and subjective satisfaction.

\subsection{Research Question 6}

The sixth research question for the study was "What is the relative effect of perceived enjoyment, self-efficacy, attitude and subjective satisfaction on learner's usability of a FOSS-based learning package?" Findings obtained from this question are presented in Table 6.

Table 6 shows the relative contribution of Perceived Enjoyment, Self Efficacy, Attitude and Subjective Satisfaction on Learner's Usability of FOSS Package. The table shows that subjective satisfaction has highest contribution $(\beta=.310)$ which is followed by self-efficacy $(\beta=.280)$ also followed by perceived enjoyment $(\beta=.180)$. Behavioral intentions had the least and a negative contribution $(\beta=-.003)$.

Table 6. Relative Contribution of Perceived Enjoyment, Self Efficacy, Attitude and Subjective Satisfaction to Learner's Usability of Foss

\begin{tabular}{|c|c|c|c|c|c|}
\hline \multirow{2}{*}{ Model } & \multicolumn{2}{|c|}{$\begin{array}{c}\text { Unstandardized } \\
\text { Coefficients }\end{array}$} & $\begin{array}{c}\text { Standardized } \\
\text { Coefficients }\end{array}$ & $\mathrm{T}$ & Sig. \\
\cline { 2 - 5 } & $\mathrm{B}$ & $\begin{array}{c}\text { Std. } \\
\text { Error }\end{array}$ & Beta & & \\
\hline Constant & 5.225 & 2.007 & & 2.603 & .011 \\
\hline Self Efficacy & .446 & .161 & .280 & 2.776 & .007 \\
\hline $\begin{array}{c}\text { Behaviour } \\
\text { Intentions }\end{array}$ & -.003 & .109 & -.003 & -.024 & .981 \\
\hline $\begin{array}{c}\text { Subjective } \\
\text { Satisfaction }\end{array}$ & .145 & .054 & .310 & 2.686 & .009 \\
\hline $\begin{array}{c}\text { Perceived } \\
\text { Enjoyment }\end{array}$ & .124 & .089 & .180 & 1.394 & .167 \\
\hline
\end{tabular}




\section{Discussion, Conclusion and Recommendations}

\subsection{Discussion}

The results obtained from statistical analyses on the research questions (Tables 1 and 4) indicated that the levels of acceptability and usability of the FOSS-based package are high (Mean $=5.14$ and Mean=3.35 respectively) for teaching and learning among the engineering and technology students. Moreover, self efficacy, attitude and subjective satisfaction collectively impacted learners' acceptability of the FOSS-based package for learning (Table 2). When the three independent variables (self-efficacy, attitude and subjective satisfaction) were put together, they accounted for about $24.3 \%$ of the total variance in the learner's acceptability of the FOSS-based package (Adjusted $\mathrm{R}^{2}=$ 0.243). Also, perceived enjoyment, self-efficacy, attitude and subjective satisfaction impacted significantly on learners' usability of the FOSS-based package. Collectively, the four independent variables (perceived enjoyment, self-efficacy, attitude and subjective satisfaction) accounted for about $29.9 \%$ of the total variance in the learner's usability of the FOSS package (Adjusted $\mathrm{R}^{2}=0.299$ ). While self-efficacy and subjective satisfaction have positive contributions to both acceptability and usability, attitude had the least contributions to both (positive at acceptability and negative at usability). However, perceived enjoyment was found significant to learner's usability of the FOSS-based learning package.

The levels of acceptability and usability of the FOSSbased learning package were high and were influenced by independent variables (self efficacy, subjective satisfaction, attitude and perceived enjoyment). These findings agree with [14] that information technology systems that are easier to use will be less threatening to the individual. This is supported by [22], and [10] that perceived usefulness strongly influences peoples' intentions. They also indicated that perceived ease of use had a small but significant effect on intentions although this effect subsided over time; whereas, attitudes partially mediated the effects of these beliefs on the intentions [10,22]. In the findings, perceived usefulness and ease of use are each highly correlated with self-reported use and future use [20]. Ease of use appears to be a causal antecedent of usefulness, with little direct effect on use [15]. As discovered, users of new technology often experience cognitive dissonance in understanding the benefits of using the new technology, while still being resistant to change and uncertainty. Besides, the user's current level of satisfaction with computer and technology influenced their future usage of new technology and software. Reference [20] however, found that one's actual use of a technology system is influenced by the user's behavioral intentions, attitude, perceived usefulness of the system, and perceived ease of use of the system.

Meanwhile, self-efficacy relatively influenced the level of acceptability and usability of the package and is supported by [5] that self-efficacy is an important determinant of successful computer adoption. Self efficacy regarding computer usage is an individual's belief regarding his or her ability to successfully master a computer. Previous research has shown that high self- efficacy and/or computer self-efficacy has influenced technology use [14].

Contrary to findings by [15], that attitude would be a direct predictor of the intention to use technology, which in turn would predict the actual usage of the technology, attitude was found to be a weak predictor of the acceptability and usability of the package in this study; this agrees with [3] that attitude would not play a significant role but rather that perceived ease of use (expectation that a technology requires minimum effort) and perceived usefulness (perception that the use of a technology can enhance performance of a task at hand) determines the intention to use a technology.

The acceptability and usability were relatively influenced by subjective satisfaction and perceived enjoyment which corroborates [15] that subjective satisfaction was found to be a significant factor in affecting learners' intention to use e-learning. It also agrees with [12] that Nurses using the computer reported greater satisfaction with CAI. Reference [16] also found that visualization and interactivity are key factors in accepting and using technology for learning. Reference [22] also supported by [21] found that in terms of technology acceptance and use, perceived enjoyment is the antecedent of future use.

\subsection{Conclusion}

Based on the findings of this study, it can be concluded that the levels of acceptability and usability of the MsLCDS learning package are high. Also, learner's acceptability of the FOSS-based learning package is based on self efficacy, attitude and subjective satisfaction while learner's usability of the FOSS-based package is based on perceived enjoyment, self efficacy, attitude and subjective satisfaction. Subjective satisfaction has highest contribution to both learner's acceptability and usability followed by self efficacy, attitude has the least contribution. Perceived enjoyment has positive contribution to user usability.

\subsection{Recommendation}

It is recommended that existing misconceptions in various areas of science and engineering courses be determined and development of suitable computer assisted materials or packages be made. Considering the acceptability and usability levels of the learning package used in this study, teachers can be asked to take part in inservice training and can be taught how to use the programs such as Microsoft LCDS, Photostory, Drag and Drop Game, Macromedia Flash, Macromedia Authorware, Adobe Photoshop in preparing science/engineering based instruction. They can be encouraged to develop the computer-based science and technology software. This study can as well be replicated by carrying out a comparative study among different institutions running electrical and electronics courses. Similar research can be conducted in different higher institutions in the country.

\section{References}

[1] Altun, T, Yigit, N. \& Alev, N. "The Effects of Computer Supported Materials on Student Achievements and Perceptions in 
Science Education", in Conference IMCL 2007, Amman, Jordan. 18-20, April 2007.

[2] Bakac, M, Tasoglu, K. A. and Akbay, T, "The effect of computer assisted instruction with simulation in science and physics activities on the success of student: Electric current", Eurasian Journal of Physics and Chemistry Education, 1(1), 34-42. Jan. 2011.

[3] Bertrand1, M. and Bouchard, S, "Applying the technology acceptance model with people who are favorable to its use". Journal of Cyber Therapy \& Rehabilitation, 1(2), 200-210. 2008.

[4] Brinkmann, D. T, "Corporate developments and strategic alliances in e-learning". Journal of Education and Training, 43(5), 256-267. 2005.

[5] Burkhardt, B. Designing Educational Systems: Creating Our Future in a Changing World. Educational Technology Publications, 1994.

[6] Busari, O.O, Towards Rethink of Science and Technology Education in Nigeria, Mukugamu \& brother Ent., 2004.

[7] Erdat, C, "Open source software in teaching physics: A case study on vector algebra and visual representations", The Turkish Online Journal of Educational Technology, 5(1), 1303-1321, 2006.

[8] Govindasamy, T, "Successful implementation of e-learning pedagogical considerations", Journal of Internet and Higher Education, 4 (1), 287-299. 2002.

[9] Grigory, G, Gerard, C and Jon, B. Flexible Learning in a Digital World: Experiences and Expectations, Kogan Page, London, 2009.

[10] Ithaka, J. D, "User acceptance of computer technology: A comparison of two theoretical models", Journal of Management Science, 35(8), 90-104. 2011.

[11] Joseph G.Q, Karen, K, David, R, Linda, C. and Angela, M, "Computer-based learning packages have a role, but care needs to be given as to when they are delivered", Journal of Educational Development and Biological Sciences, 23(3), 99-113. 2009.

[12] Nurse, R, "Computer-Assisted Versus Traditional Classroom Instruction to Promote Change in the Nursing Management of the Second Stage of Labor," Unpublished Ph.D. Thesis. Department of Science Education, Texas Woman's University, Denton, Texas. 2009.
[13] Olasumbo S. A. and Ogunbiyi O,” Learning and Teaching Styles in Language, Science and Technology Education in Nigeria", British Journal of Arts and Social Science, .5(2), 155-162. 2012.

[14] Ong, C. S. and Lai, J. Y, "Gender differences in perceptions and relationships among dominants of e-learning acceptance". Journal of Computers in Human Behavior, 22(5), 816-829. 2006.

[15] Park, S. Y, "An analysis of the technology acceptance model in understanding university students' behavioral intention to use elearning", Journal of Educational Technology and Society, 12 (3), 150-162. 2009.

[16] Rothney, M. P, Roselli, R. J. and Howard L. P, "Creation of an Online Vector Addition Tutorial: Exploring the Advantages of Providing Diagnostic, Multilevel Feedback in Basic Skills Remediation". In ASEE Annual Conference, (CD-ROM DEStech Publications) Session 2793: 7 pages, 2003.

[17] Serin, O, "The effect of the computer-based instruction on the achievement and problem solving skills of the science and technology students". The Turkish Online Journal of Educational Technology, 10(1), 183-201. Jan. 2011.

[18] Rod Dixon. (2006). Open Source Software Law. Retrieved from http://books.google.com/books?id=9b_vVPf53xcC\&pg=PA4\&dq $=\% 22$ free+software $\% 22+$ freeware\#PPA4,M1 on 16th March, 2009.

[19] Umoren, G, "A science-technology-society paradigm and Cross River State secondary school students' scientific literacy: problem solving and decision making," Educational Research and Review 2(4), 082-091. 2007.

[20] Venkatesh, V. and Davis, F. D, "A theoretical extension of the technology acceptance model: Four longitudinal field studies," Journal of Management Science, 46(2), 186-204. 2000.

[21] Venkatesh, V. and Morris, M. G, "Why don't men ever stop to ask for directions? Gender, social influence, and their roles in technology acceptance and usage behavior," MIS Quarterly, 24(1), 115-140. 2000.

[22] Wenchieh, W. and Hwang, L. Y, "The effectiveness of e-learning for blended courses in colleges: A multi-level empirical study," International Journal of Electronic Business Management, 8(4), 312-322. 2010. 